\title{
K filozofickému diskurzu literárnej moderny
}

\section{ZUZANA KOPECKÁ}

DOI: https://doi.org/10.31577/WLS.2021.13.4.12

Akýkolvek exkurz do dejín západnej filozofie dokazuje skutočnost', že v odpovediach na filozofické otázky, ktoré vznikajú v snahe porozumiet človeku a svetu okolo neho, sa opätovne objavujú tendencie odhalit princíp všetkého - arché pantón. ${ }^{*} \mathrm{Z}$ velkej časti ide o metafyzický rozmer filozofického myslenia, ktoré by mohlo tvorit základ pre univerzalistické projekty určujúce zmysel a smer mikrokozmu človeka v makrokozme sveta, čo je príznačné už pre ranú grécku filozofiu. No tradíciou vytvorený fundament s mýticko-náboženským obsahom univerzálnej platnosti už v ranej gréckej filozofii postupne doplňajú antropologické prvky. ${ }^{1}$ Tie predznamenávajú centrálne postavenie človeka, ktorý racionalizuje mýtické, a tým anticipuje prechod od mýtu k logu. „[P]oprvé na světě se sebe-vědomí člověka povzneslo k pojmu jeho zvláštního postavení tvrzením, že člověk je člověkem proto, že má ,rozum', logos, fronesis, ratio, mens" (Scheler [1928] 1968, 44). Cesta k porozumeniu sa teda v danom momente má uskutočňovat’ cez rozumom obdarenú bytost', avšak aj napriek jej intelektuálnemu potenciálu je ešte podriadená transcendentnu - osudu, ktorý schopnosti človeka presahuje a zaraduje ho do univerzálneho svetového poriadku. $\mathrm{V}$ podobných intenciách sa učenie sofistov odvija od Protagorovho chápania „človeka ako miery všetkých vecí “ či stredoveké krestanské myslenie, ktoré taktiež nevylučuje jedinečné postavenie človeka, ale pripisuje mu jasne určený základ $\mathrm{v}$ absolútnom a nekonečnom bytí Boha - v objektívnom svetovom poriadku.

Účast človeka (indivídua, ktoré sa postupne mení na masu) na rozpade tohto univerzalizmu spočíva $\mathrm{v}$ závislosti jeho viery $\mathrm{v}$ transcendentno od vonkajšku, a teda od zviditel’nenia pochybení v cirkvi prerastajúcich do krízy a demoralizácie. Nasledujúcu reformáciu v cirkvi potom doplňa aj „kopernikovský obrat“, ktorý znamená úplnú zmenu dovtedajšieho obrazu sveta a človeka $\mathrm{v}$ ňom. ${ }^{2}$ Emerich Coreth tento rozpad univerzalizmu opisuje ako absolútnu zmenu ludskej pozície, ktorá určuje spôsob filozofického myslenia v novoveku, pričom človeka tu vníma ako indivíduum, ktoré je schopné uvažovat v kozmických dimenziách:

[Človek] dosud žil ve středu jasně uspořádaného a přehledného světa. Jeho Země, kolem níž obíhalo Slunce a souhvězdí, byla středem univerza, jež se dovršuje v člověku. Nyní však, když Země už není středem vesmíru, nýbrž jako jedna z planet obíhá kolem Slun-

* Štúdia vychádza z dizertačnej práce autorky s názvom „Symptómy literárnej moderny v slovenskej a českej medzivojnovej próze" obhájenej 24. 8. 2021 v Ústave svetovej literatúry SAV v Bratislave. 
ce, cítí se člověk jakoby vyvržen do nesmírného univerza, které už nemưže přehlédnout a v němž ztrácí veškerou orientaci a bezpečí. Nemá už ve vesmíru žádné zajištěné stanoviště. Objektivní skutečnost mu už nezaručuje smysl a místo jeho bytí. Tím více je vržen zpět na sebe sama, na jediný jistý bod, který je mu dán. To jej nutí, aby uvažoval sám o sobě a tázal se po podstatě člověka a po smyslu jeho života $(1996,29)$.

$\mathrm{Aj}$ napriek tomu, že Coreth zvažuje iný typ univerzalizmu a jeho rozpadu v dôsledku poznania nových skutočností, pre formujúci sa charakter novovekej filozofie je uvedená zmena pozície človeka v zmysle „vytrhnutia“ z pevných štruktúr sveta a následnej koncentrácie na seba nosná, ${ }^{3}$ kedže logocentrická "gravitácia k sebe“, ktorá profiluje už antické a neskôr aj stredoveké filozofické myslenie, sa vstupom do racionalizmu karteziánskeho obdobia subjektivizuje. Rozdiel v nazeraní na človeka, ktorý sa v tejto fáze stáva subjektom, totiž spočíva primárne $\mathrm{v}$ apele na autonómiu ludského rozumu spolu s podnietením sebauvedomovacieho procesu a spochybnením moci božskej autority:

Člověk jako pouhý subjekt se stává středem, ne však středem objektivního řádu bytí, nýbrž stř̌edem subjektivního světa poznání, který - u Descarta (1596 - 1650) - nalézá bezpečné východisko v čiré jistotě vědomí (ego cogitans). Toto Já, jež si je před všemi ostatními věcmi vědomo sama sebe a jisto samo sebou, není konkrétní člověk, nýbrž jen čistý rozum (ratio), který autonomně vlastní sám sebe (29).

Descartovým impulzom k zmene dovtedajšej filozofickej paradigmy sa filozofia dostala do úplne inej pozície - do oblasti subjektivity (Hegel [1833 - 1836] 1974, 233). ${ }^{4}$ Ide o metodologický posun, ktorý spočíva v istote subjektu poznat samého seba, čo je predpokladom dalšieho poznania. Slovami Descarta, „[p]ouze sám se sebou budu mluvit a hlouběji nahlížet do svého nitra, a tak se pokusím sám se sebou se více a důvěrně seznámit" ([1641] 1968, 15). Ťažiskom novej filozofickej paradigmy je potom subjekt schopný „autonómneho poznania prostredníctvom rozumu bez nevyhnutného legitimizovania tohto vedenia nejakou transcendentnou inštanciou či autoritou“ (Bakoš 2006, 782). Descartovo „cogito ergo sum“ tak napohlad vedie $\mathrm{k}$ relativizovaniu platnosti akejkolvek istoty okrem tej, ktorá spočíva $\mathrm{v}$ schopnosti subjektu mysliet', pochybovat', a teda napokon aj dôjst' k poznaniu nových „právd“. Theodor Münz opisuje Descartov prístup v uvedenej fáze hladania - v stave pochybností - nasledovne: „Predsa o každej téze možno pochybovat', a ked’ chceme nájst’ aspoň jednu celkom nepochybnú, nemôžeme blúdit’ kdesi v metafyzických končinách, ale sa musíme vtiahnut' hlboko do svojho subjektu [...]. Len poznávanie našich vnútorných zážitkov je celkom isté“ $(1967,9)$. Metafyziku, ktorá má korene za hranicami prírodného zmyslovo-predmetného sveta bez opory jej tažísk v priamej skúsenosti, postupne vytesňujú exaktné vedy, avšak aj „[r]acionalizmus v osobe svojho zakladatela hladá metafyzickú bázu, kde sa môže myšlienková špekulácia uchytit’ a obhájit’ samu seba. Vmyslený priestor ,pevného bodu' venuje Descartes metafyzike“ (Gerbery 2010, 62). K záveru, že súčastou poznania je aj jeho transcendentný rozmer, ktorý v určitom stave pochybností človek odmieta či stráca, tak napokon prichádza aj samotný Descartes. Na rozdiel od Leibniza totiž u personálneho a autonómneho „ja“ zostáva iba dovtedy, pokým nepredloží záver o ludskej nedokonalosti v porovnaní s dokonalostou, ktorá je obsiahnutá výlučne v existencii Boha a jeho vôli presahujúcej 
človeka (Descartes [1641] 1968, 23). Na jednej strane je tu obraz človeka ako autonómnej, aj ked'konečnej rozumovej bytosti, a oproti nej stojí koncepcia nekonečného Boha ako určujúceho duchovného princípu - táto protirečivost je napokon charakteristická pre nasledujúci vývoj filozofického myslenia v 17. a 18. storočí na pozadí sporu empirizmu s racionalizmom.

V súvislosti s uvedeným filozofickým diskurzom sa napokon dostávame $\mathrm{k}$ pojmu moderna. Aj ked' je moderna interpretovaná $\mathrm{z}$ viacerých spoločenskovedných hladísk, jediné, čo rezonuje vo väčšine definícií vztahujúcich sa na rôzne oblasti uplatnenia daného pojmu, je kardinálna otázka postavenia subjektu - charakteru jeho autonómie a vztahu k ostatným inštanciám, ktorá je spätá (najmä v európskom kontexte) s fenoménom viery. Benjamin Woolley charakterizuje modernu ako éru $\mathrm{v}$ histórii, ktorá nasleduje po renesancii alebo sa začína osvietenstvom, teda v čase, ked' myšlienky technologického pokroku a objavovanie nových poznatkov rozumu a vied začali podkopávat autoritu náboženstva $(1993,171)$. Vychádzajúc z nivelizovania vztahu človeka k Bohu racionalizmom karteziánskeho obdobia Mária Bátorová explikuje pojem moderna podla Wolfganga Welscha a popri novovekej moderne rozlišuje ešte radikálnu modernu 20. storočia, kde už „klíči“ postmoderna (Welsch 1987 [Bátorová 2018, 205]). No popri zmene vzt̉ahu medzi človekom a Bohom, ${ }^{5}$ ktorý je podmienený najmä relativizovaním objektívneho svetového poriadku v zmysle náboženskej dogmy, je v moderne určujúcim činitelom antropologický obrat $\mathrm{k}$ subjektu príznačný práve pre karteziánske obdobie. Ide o základ modernej individuality schopnej prostredníctvom introspekcie, teda cez sebapozorovanie a sebaporozumenie, imanentne pochopit svet, ktorý dokáže menit a ovládat', a to až do okamihu, ked' vo svojich cieloch zlyháva:

To, co se od druhé poloviny 19. století až do první světové války jevilo jako velký pokrok lidstva, z čeho vyrůstal racionalismus od 17. a 18. století, co vyústilo ve Francouzskou revoluci a politicky se ztělesnilo $\mathrm{v}$ struktuře moderní demokracie, bylo pokládáno za jednoznačně pozitivní perspektivu vývoje společnosti. Všeobecně se rozšrírila víra $\mathrm{v}$ pokrok, který je spojen s lidským věděním a poznáním, s podmaňováním přírody. [...] Optimistický trend vývoje průmyslové společnosti narušila už první světová válka. Ta náhle ukázala nejen problémy vědeckotechnického rozvoje, ale odhalila nebezpečí dosavadního civilizačního procesu - nebezpečí, jež mu hrozí, není-li vyvažován etickými komponentami. Tento proces nezvládla ani lidská psychika a vyvstala otázka, je-li šablona nepřetržitého pokroku vůbec relevantní lidskému individuu. Stejně tak problematickým se ukázalo přesvědčení o tom, že člověk je pánem přírody, kterou si osvojuje a podřizuje svým zájmům (Kautman [1999] 2000, 76 - 77).

Presvedčenie, že človek disponuje schopnostou ovládnut svojím rozumom všeobecne platné zákony, prírodné vedy, umenie i náboženstvo, ho totiž situuje do kritického štádia existencie $\mathrm{v}$ momente otrasu, $\mathrm{v}$ dôsledku ktorého dovtedajšie princípy univerzálneho systému racionality (osvietenskej jednoty, homogénnosti a kauzality) zrazu neplatia a nový poriadok ešte nie je vytvorený či všeobecne akceptovaný. Excentrická ludská bytost’ preto začne opät hladat’ „nejaký pevný bod v transcendentne, ${ }^{6}$ kedže ho nemôže nájst' vo svojom životnom prostredi' (Šlosiar 2014, 43) v zmysle karteziánskeho cogitans. Slovami Friedricha Nietzscheho, Descartova „viera v istotu myslenia je iba dalšia viera a žiadna istota" ([1883] 2011, 196). Je to do určitej 
miery cyklický proces spočívajúci na zlomoch $\mathrm{v}$ spôsoboch uvažovania a dokazovania nových istôt a „právd“. Relativizovanie racionálnych zákonitostí alebo svätých náboženských dogiem či argumentov metafyziky totiž paralelne vedie $\mathrm{k}$ spochybneniu viery v akýkolvek princíp univerzalizmu, resp. viery ako takej. Práve na tomto mieste sa profiluje samotná podstata moderny, kedže, ako hovorí teoretik postmoderny Jean-François Lyotard, s modernou, akokolvek ju datujeme, vždy súvisí otras viery a objav „malej reálnosti reality“ - bezpochyby ako dôsledok objavenia iných realít ([1982] 1993, 23).

Priblížením podstaty moderny z hladiska vývoja filozofického myslenia vztahujúceho sa $\mathrm{k}$ človeku-subjektu ako $\mathrm{k}$ antropocentrickej konštante, ktorá introspekciou dokáže reflektovat samu seba, a tak vníma aj otrasy vonkajšieho sveta, predznamenávame dalšiu fázu v konštituovaní významu tohto pojmu v nadväznosti na antropologické prúdy poklasickej filozofie 19. storočia a modernej filozofie 20. storočia. Friedrich Nietzsche cez postavu Pomätenca v Radostnej vede vyslovil: „Kam se poděl Bůh? [...] ja vám to povím! My jsme ho zabili, - vy a já! My všichni jsme jeho vrahy! Ale jak jsme to udělali? [...] Bůh je mrtev! Bůh zůstane mrtev!“ ([1883] 2011, 61). Zodpovedného za smrt’ Boha Nietzsche činil práve človeka. Vladimír Papoušek v tejto súvislosti považuje koniec 19. storočia za dobu, kde „nepanuje božský rád chápaný člověkem jako srozumitelné dobro, nýbrž chaotický pohyb neznámých sil, které ztrácejí antropologickou podstatu a jsou už jenom nesrozumitelnými, cizími elementy“ $(2010,44)$. Spoločným východiskom antropologických prúdov je aj napriek mnohým vzájomným odlišnostiam individuálna skúsenost jednotlivca, jeho osobné prežívanie a existencia vo svete, ktorý ho obklopuje. Slovami Štefana Juska interpretujúceho filozofiu Friedricha Nietzscheho, „seriózne uchopenie vlastnej existencie bez sveta, v ktorom sa tvorila, je nemožné alebo čisto naivné [...], problematickost' sveta je teda aj v nás samých“ (2018, 78 - 79). Podobne aj Sigmund Freud odvodzuje túto problematickost od zmeny postavenia človeka ako iniciátora a realizátora masívneho pokroku 19. storočia vo vztahu k božským inštanciám:

[Človek] všetkými svojimi nástrojmi zdokonaluje svoje orgány - motorické aj senzorické - alebo odstraňuje prekážky pre ich použitie. Motory mu poskytujú obrovské sily, ktoré môže ako svoje svaly uplatnit' v lubovolnom smere, lod’ a lietadlo mu umožňujú pohyb, pričom mu neprekáža voda či vzduch. Okuliarmi môže korigovat chyby šošovky vo svojom oku, dalekohladom pozerá do dialok, mikroskopom prekonáva hranice viditelnosti určené stavbou jeho sietnice. [...] Všetky tieto výhody môže považovat za svoje kultúrne vlastníctvo. Dávno si vytvoril ideálnu predstavu o všemohúcnosti a vševedúcnosti, ktorú stelesnil vo svojich bohoch. Im pripisoval všetko, čo sa zdalo nedosiahnutelné pre jeho želania - alebo čo mu bolo zakázané. Môžeme teda povedat, že títo bohovia boli kultúrnymi ideálmi. Teraz sa dosiahnutiu tohto ideálu vel’mi priblížil, sám sa stal takmer Bohom. [...] Človek sa stal takpovediac istým druhom Boha s protézami. Je dost velkolepý, ked je opatrený všetkými svojimi pomocnými orgánmi, ale nezrástli s ním a občas mu robia ešte velké tažkosti. [...] Budúce časy prinesú v oblasti kultúry nový, pravdepodobne nepredstavitelný pokrok a ešte dalej vystupňujú podobnosł človeka s Bohom. [...] [N] esmieme zabudnút, že sa dnešný človek vo svojej podobnosti Bohu necíti šlastný ([1929] 2014, $114-115)$. 
Freudovo zdôraznenie nespokojnosti človeka v kultúre (spoločnosti) je zároveň poukázaním na moment, ked' sa prejavy spoločenského poriadku, brzdiaceho pudový potenciál každej bytosti, a dôsledky kultúrneho pokroku javia ako počiatok krízy sveta objektivizovaného racionalizmom, podobne ako tomu bolo v osvietenstve, kedže „nadměrná nabídka informací a racionalistických pravd činí racionální orientaci v ní nemožnou" (Liessmann 2000, 182). Proti objektivizácii sveta a jeho poriadku sa preto čoraz výraznejšie zdôrazňuje subjekt, t. j. moderný človek, ktorý sa podla Danila Martuccelliho „cítí znepokojený obrovským počtem objektivních obsahů a materiálními požadavky [...], musí hrát různé role, musí používat sociální formy, aniž by se kdy s nimi mohl zcela ztotožnit. V každém okamžiku tak hrozí, že se vnější formy vzdá a uzavře se zcela do své bezprostřední subjektivity“ (2008, 328). Martuccelli (v nadväznosti na Georga Simmela) takto vystihuje podstatu moderného konfliktu, odohrávajúceho sa v oblasti ludskej subjektivity, teda v psychickom prežívaní indivídua reagujúceho na charakter vonkajšieho sveta. „[M]oderní člověk začíná vidět, že každý pokrok ve vnějším světě vytváří také stále vzrůstající možnost ještě větší katastrofy" (Jung [1927] 1994, 14), o čom napokon svedčí najmä charakter 20. storočia zakódovaný v dvoch svetových vojnách. Jedným z dôsledkov je potom dištancia od vonkajšieho sveta paralelne s vtiahnutím do sveta vlastnej subjektivity.

K zaznamenávaniu problematického rozmeru pokroku spoločnosti s dôrazom na individuálne prežívanie subjektu dochádza $\mathrm{v}$ zmene filozofickej paradigmy v 19. storočí a na prelome 20. storočia, na základe čoho sa profiluje filozofia života, filozofia existencie či filozofická antropológia. ${ }^{7} \mathrm{Aj}$ v tomto prípade ide o mimoliterárny kontext umenia moderny, ktoré sa vo svojej radikálnejšej podobe stáva akýmsi poplašným antropologickým javom zaznamenávajúcim permanentnú krízu subjektu v 20. storočí. Ako problematické sa javí aj samotné dobové ponímanie človeka a jeho zvláštneho miesta vo svete 20. storočia. Podla Maxa Schelera sa „v žádném dějinném období nestal člověk tak problematickým jako v současnosti“ ([1928] $1968,44)$. Na mieste, kde táto problematickost’ stojí za spôsobom myslenia a uvažovania o človeku, sa formuje síce heterogénne umenie, no aj napriek rôznorodosti autorských konceptov dokážeme nachádzat ich spoločného menovatela. Slovami Konrada $\mathrm{P}$. Liessmanna, „[k]dyž všechny ostatní výklady a důvody existence, jako např. náboženské [...], zestaraly, pak zbývá estetické pozorování, pak zbývá umění jako jediná možnost, jak propůjčit existenci smysl. [...] Moderna je také epochou, v níž umění, at chce nebo ne, je vždy znovu nuceno přistoupit na dědictví ztracené religiozity“ $(2000,70)$. Uvedená problematickost ${ }^{8}$ však nie je umelecky vyjadrená romantickým, priam transparentným gestom revoltujúceho jednotlivca proti spoločnosti, ${ }^{9}$ ale transformuje sa do podoby vnútornej rozorvanosti, ktorú moderný subjekt pocituje na základe schopnosti introspektívnej reflexie. Filozofický základ moderny sa tak pretransformoval aj do oblasti estetiky, teda do špecifickej podoby umenia moderny - literárnej aj výtvarnej. 


\section{POZNÁMKY}

1 „Kreovanie tragického mýtu sa odohralo na pôde umenia, čím sa malo ozrejmit, že Gréci tradíciou vytvorené mravy, celú oblast' sociálneho správania, vnímali, prinajmenšom od 9. storočia p. n. l., ako maškarádu bohov a ludí, teda ako sveta krásneho zdania, umelecky. Umelecké cítenie (hodnotenie) mravov prerástlo do morálneho citu, kreovaného rozumom až $\mathrm{v} 5$. storočí p. n. 1., a to v podobe, resp. cez jej prototyp - Sokrata. [...] Sokratova múdrost' v obrate poznania človeka [...] spočívala v poznaní seba samého, a nie človeka vôbec. [...] Sokrates totiž upriamením pozornosti na ja predstavuje umenie individuálneho života, čo neskôr F. Nietzsche považuje za prejav odklonu od krestanstva“ (Jusko 2018, 97 - 98, 105, 114).

2 O vplyve geocentrického modelu Mikuláša Kopernika, ktorý bol následne rozvinutý Johannom Keplerom a Giordanom Brunom, na psychickú dispozíciu novovekého človeka „strateného“v nekonečnom kozmickom priestore hovorí aj Sigmund Freud, ked' takúto zmenu vymedzuje ako prvý úder pre postavenie subjektu vo vztahu $\mathrm{k}$,naivnej sebaláske“: „Lidstvo muselo v průběhu věků strpět ze strany vědy dvě velké újmy pro svoji naivní sebalásku. První újmou bylo poznání, že naše země není středem vesmíru, nýbrž jen nepatrným dílečkem světové soustavy, její̌ velikost si lze stěží představit. Tato újma je pro nás spjata se jménem Koperníkovým, třebaže něco podobného prohlašovala už alexandrijská věda. Druhá újma přišla, když biologické bádání zlikvidovalo domnělou výsadu člověka být tvorem Božím a přimělo ho smířit se s tím, že má svůj původ ve zviřrecí ř́šii a že jeho živočišná přirozenost je čímsi nesmazatelným. K tomuto přehodnocení došlo za našich dnů vlivem $\mathrm{Ch}$. Darwina, Wallace a jejich předchůdcü“ ([1916 - 1917] 2020, 204). Freud však vo svojej práci pokračuje aj tretou, najcitlivejšou ujmou, za ktorou vidí psychoanalýzu, ktorá odhalením nevedomých obsahov dokazuje ludskému ja, že „není pánem ani ve svém vlastním domě“ (204).

3 Podobne uvažuje aj Carl G. Jung, ktorý identifikuje moderné vedomie odkláňajúce sa od vedomia stredovekého človeka a obracia sa k sebe samému, čím plodí mnohé duševné javy, ktoré boli dovtedy v najhlbšom tieni ([1927] 1994, 14): „Podívejme se, jak odlišně vypadal svět stř̌edověkého člověka: Země byla středem světa, věčně stálá a nehybná, kolem ní obíhalo starostlivé slunce, dárce tepla. Všichni bílí lidé byli dětmi Boha, který o ně láskyplně pečoval a choval je pro věčnou blaženost, a všichni přesně věděli, co mají dělat a jak se mají chovat, aby $z$ pozemské pomíjivosti dospěli $k$ věčnému a radostnému bytí. $O$ takové skutečnosti si už nemůžeme dát ani zdát. Př́rodní vědy tento půvabný závoj dávno potrhaly“ (14).

4 Jean-François Lyotard popri Descartovi zdôrazňuje Augustina - obaja podla neho znamenajú začiatok tradície filozofie subjektu ([1982] 1993, 24).

5 Následne po nivelizovaní vztahu človeka k Bohu racionalizmom karteziánskeho obdobia je to podla Bátorovej francúzska moderna, ktorá sa začína Charlesom Baudelairom a ktorá postavila človeka vedla Boha $(2011,62)$. Bátorová tiež zdôrazňuje Baudelairov pohlad na počiatok moderny u Francisca Goyu $(2000,137)$, pričom španielska moderna Boha karikovala (groteskný výraz ako výsmech súdobej spoločnosti či karikovanie božskej autority) a pod. V roku 1917 Hugo Ball interpretuje vztah človeka k Bohu, v nadväznosti na „smrt’ Boha“ Friedricha Nietzscheho, nasledovne: „Bůh je mrtev. Jeden svět se zhroutil [...] Smysl světa je pryč. [...] Propukl chaos. [...] Člověk ztratil svůj nebeský vzhled, změnil se v matérii, náhodu, konglomerát, zvíře, šílený výtvor. [...] Člověk přišel o zvláštní postavení, jež mu bylo zaručováno rozumem“ (Murphy 2010, 55). Je však potrebné upozornit aj na prúd vo svetovej i slovenskej literatúre, ktorý počíta s kategóriou Boha (a to aj v období prelomu 19. a 20. storočia, ktoré sa v literárnej moderne prejavuje ako obdobie absencie Boha), ale si ju modifikuje. Človek sa tu prepadá $\mathrm{k}$ Bohu vo svojom vnútri, kde ho hladá a napokon i nachádza (napr. tvorba Rainera M. Rilkeho; Welsch 1987 [Bátorová 2016, 11 - 12]), umelec vníma Boha ako existujúcu entitu (Paul Claudel, Franz Werfel, Ernst Barlach), a tak vzniká transcendentný prúd moderny, ku ktorému patrí aj tzv. katolícka moderna (Bátorová 2010).

6 Ak transcendencia znamená presah, prekročenie zmyslovej skúsenosti, teda prechod k nadzmyslovému alebo $\mathrm{v}$ užšom význame $\mathrm{k}$ nadsubjektívnemu božskému princípu, metafyzika je možnostou, pomocou ktorej sa tento prechod podstupuje (Gerbery 2010, 64).

7 Max Scheler ako zakladatel' filozofickej antropológie je autorom diela s presahmi do fenomenológie Miesto človeka v kozme (1928), kde predkladá celostné chápanie človeka schopného sebauvedomenia. 
Scheler na jednej strane akceptuje vedecké poznatky o človeku, no zároveň ho vníma ako duchovnú bytost', ktorá prekračuje rámec „objektívnej“ vedy a smeruje k metafyzike (Kiczko a kol. 1993, 119). Pritom „[c] esta ducha $\mathrm{k}$ absolútnu, Bohu, metafyzickému naplneniu nevedie cez kozmos, ale cez vnútro duchovnej osoby“ (120). Ďalšími predstavitelmi sú napr. Helmut Plessner či Arnold Gehlen.

8 Mária Bátorová sa $\mathrm{k}$ otázke vztahu moderny $\mathrm{k}$ stratenej alebo hladanej religiozite vyjadruje nasledovne: „Zdalo by sa, že moderna, tak silno koncentrovaná na človeka, automaticky vylúči krestanskú tvorbu, no nestalo sa tak. [...] Silný prúd krestanskej filozofie (Gabriel Marcel), literárnej a výtvarnej moderny pokračuje od Paula Claudela, cez Franza Werfela, Ernsta Barlacha, Giovani Papiniho, Grahama Greena a iných svetových autorov do dnešných dní. Títo autori, každý svojím spôsobom, priniesli diela, ktoré riešia ontologické otázky človeka, ku ktorým otázka nadzmyslového - transcendentného sveta patri' $(2016,12)$.

9 Analógie medzi literárnou modernou a romantizmom zaznamenáva aj Bátorová, ked’ literárnej moderne pripisuje charakter novoromantického smeru (2011, 24), ktorý dodržiava rytmus „obkročného" výskytu podobných znakov literárnych smerov.

\section{LITERATÚRA}

Bakoš, Vladimír. 2006. „Spory o modernost’ v slovenskom (filozofickom) myslení.“ Filozofia 61, 10: 775 - 793.

Bátorová, Mária. 2000. Jozef Cíger Hronský a moderna. Bratislava: Veda, vydavatel'stvo SAV.

Bátorová, Mária. 2010. „Krestanská tvorba na Slovensku po roku 1945 (alebo jeden z typov alternatívnej tvorby na Slovensku po roku 1945).“ In Slovenská krestanská kultúra - Osudy a osobnosti, ed. by Marta Žilková, 19 - 30. Ostrihom: Vysoká škola teologická.

Bátorová, Mária. 2011. Slovenská literárna moderna v spektre svetovej moderny (Jozef Cíger Hronský). Martin: Matica slovenská.

Bátorová, Mária. 2016. „Vztah náboženstva a umenia v literatúre svetovej a slovenskej moderny.“ Slavia occidentalis 73, 2: 7 - 23.

Bátorová, Mária, 2018. „Pavol Strauss.“ In Pavol Strauss, prorok novej evanjelizácie, ed. by Tibor Žilka Ján Gallik, 205 - 213. Gelnica: G-Ateliér.

Coreth, Emerich. 1996. Co je člověk? Základy filozofické antropologie. 2. vydanie. Prel. Bohuslav Vik. Praha: Zvon, české katolické nakladatelství.

Descartes, René. [1641] 1968. Úvahy o první filosofii. Prel. Zdeněk Gabriel. Praha: Státní pedagogické nakladatelství.

Freud, Sigmund. [1929] 2014. „Nespokojnost’ v kultúre.“ In O človeku, kultúre a náboženstve, Sigmund Freud, prel. Milan Krankus, 90 - 164. Bratislava: Európa.

Freud, Sigmund. [1916 - 1917] 2020. Přednášky k úvodu do psychoanalýzy. Prel. Jiří Pechar. Praha: Portál.

Gerbery, Tomáš. 2010. „Metafyzika konca metafyziky (Niekolko poznámok k súčasnej potrebe transcendencie). “ In Personalizmus a súčasnost' I., ed. Pavol Dancák - Dušan Hruška - Marek Rembierz - Radovan Šoltés, 61 - 69. Prešov: Prešovská univerzita v Prešove.

Hegel, Georg Wilhelm Friedrich. [1833 - 1836] 1974. Dějiny filosofie III. Prel. Jiří Bednár - Jindřich Husák. Praha: Academia.

Jung, Carl Gustav. [1927] 1994. Duše moderního člověka. Prel. Karel Plocek. Brno: Atlantis.

Jusko, Štefan. 2018. Sokratovská otázka ako filozofický problém. Košice: Filozofická fakulta Univerzity Pavla Jozefa Šafárika v Košiciach.

Kautman, František. [1999] 2000. „Dostojevskij, Kafka, Hostovský: existenciální problematika moderní prózy.“ In Sborník prací Filozofické fakulty brněnské univerzity: Bohemica Litteraria 48, V2, ed. by Ivo Pospísili, 71 - 83. Brno: Masarykova univerzita.

Kiczko, Ladislav a kol. 1993. Dejiny filozofie. Bratislava: Slovenské pedagogické nakladatel'stvo.

Liessmann, Konrad Paul. 2000. Filozofie moderního umění. Prel. Jiří Horák. Olomouc: Votobia. 
Lyotard, Jean-François. [1982] 1993. „Beantwortung der Frage: Was ist postmodern?“ In Postmoderne und Dekonstruktion. Texte französischer Philosophen der Gegenwart, ed. Peter Engelmann, 33 - 48. Stuttgart: Reclam.

Martuccelli, Danilo, 2008. Sociologie modernity. Itineráŕ 20. století. Prel. Pavla Doležalová - Jana Spoustová. Brno: Centrum pro studium demokracie a kultury.

Murphy, Richard. 2010. Teoretizace avantgardy. Modernismus, expresionismus a problém postmoderny. Prel. Martin Pokorný. Brno: Host.

Münz, Teodor. 1967. Novoveká empirická a osvietenská filozofia. Antológia z diel filozofov. Bratislava: Vydavatel'stvo politickej literatúry.

Nietzsche, Friedrich. [1885] 2011. Tak pravil Zarathustra [online]. Praha: Městská knihovna v Praze. Dostupné na: https://web2.mlp.cz/koweb/00/03/40/49/81/tak_pravil_zarathustra.pdf. [cit. 17. 10. 2018].

Papoušek, Vladimír a kol., eds. 2010. Dějiny nové moderny I. Česká literatura v letech 1905-1923. Praha: Academia.

Scheler, Max. [1928] 1968. Místo člověka v kosmu. Prel. Anna Jaurisová. Praha: Academia.

Šlosiar, Ján. 2014. „Ludská prirodzenost’ a viera (Personálny rozmer ludskej prirodzenosti).“ In Personalizmus $v$ procese humanizácie ludskej spoločnosti, ed. by Pavol Dancák, 33 - 45. Prešov: Prešovská univerzita $v$ Prešove.

Woolley, Benjamin. 1993. Virtual Worlds: A Journey in Hype and Hyperreality. Londýn: Penguin Books.

\title{
On the philosophical discourse of literary modernism
}

Modernism. Subjectivity. Inner world. Introspection. Universalism.

In this study, we define philosophical discourse as one of the dominant discourses of literary modernism, whose specific authorial expressions depend primarily on the concentration on man and his inner world. This subjective world was strongly marked by the disintegration of universalism, which resulted in value relativism and the search for new "truths" capable of establishing a lost order (on a transcendental or rational basis).

\author{
Mgr. Zuzana Kopecká, PhD. \\ Ústav svetovej literatúry \\ Slovenská akadémia vied \\ Dúbravská cesta 9 \\ 84104 Bratislava \\ Slovenská republika \\ chrenkova.zuzka@gmail.com
}

